\title{
The TGF-ß3 Gene Polymorphisms and Carcass Components in Kampung x Meat Type Chicken Cross
}

\author{
Keragaman gen TGF- $\beta 3$ dan Komponen Karkas Ayam Silangan Kampung x Ras Pedaging \\ I. Khaerunnisa ${ }^{1 *}$, Jakaria ${ }^{2}, \&$ C. Sumantri ${ }^{2}$ \\ ${ }^{1}$ Faculty of Agriculture, Bandung Raya University, Jl Banten No 11. Bandung 40272 \\ ${ }^{2}$ Department of Animal Production and Technology, Faculty of Animal Science, IPB University, J1. Raya \\ Darmaga. Bogor 16680 \\ *Corresponding author: isyanakhaerunnisa@unbar.ac.id \\ (Received 31-12-2019; Revised 17-01-2020; Accepted 24-01-2020)
}

\begin{abstract}
The TGF- $\beta 3$ gene is a subtype of TGF- $\beta$ superfamily that plays a crucial role in skeletal muscle growth. The objectives of this study were to identify the TGF- $\beta 3 \mid$ BsII locus polymorphisms and to evaluate their effects on carcass components in Kampung and broiler chicken cross. A total of 129 chickens used in this study, consisting of: Kampung chickens (44), parent stock broilers Cobb strains (10), F1 Kampung $x$ broilers (35), and F2 Kampung $x$ broilers (40). The PCR-RFLP and direct sequencing techniques were used to obtain mutations in the intron 4 of TGF- $\beta 3$ gene using the BsII restriction enzyme. The TGFB3|BsII locus was polymorphic in all populations and three genotypes were found: $\mathrm{CC}, \mathrm{AA}$, and $\mathrm{CA}$. No association was found between the three genotypes with the carcass components in F2 Kampung $x$ broiler cross.
\end{abstract}

Keywords: TGF- $\beta 3$, genotypes, carcass, Kampung chicken, crossbreed

\begin{abstract}
ABSTRAK
Gen TGF- $\beta 3$ adalah anggota TGF- $\beta$ superfamili yang memainkan peran penting dalam pertumbuhan otot rangka. Tujuan dari penelitian ini adalah untuk mengidentifikasi polimorfisme lokus TGF- $\beta 3 \mid$ BsII dan untuk mengevaluasi pengaruhnya terhadap komponen karkas di ayam silangan Kampung dan ras pedaging. Sebanyak 129 ekor ayam digunakan dalam penelitian ini, terdiri dari: ayam Kampung (44 ekor), ayam pedaging strain Cobb (10 ekor), ayam Kampung $x$ ras pedaging F1 (35 ekor), dan ayam Kampung $x$ ras pedaging F2 (40 ekor). Teknik PCR-RFLP dan sekuensing digunakan untuk mendapatkan mutasi pada intron 4 gen TGF- $\beta 3$ menggunakan bantuan enzim restriksi BsII. Hasil penelitian menunjukkan bahwa lokus TGF- $\beta 3$ |BsII bersifat polimorfik pada semua populasi dan tiga genotipe ditemukan yaitu CC, AA, dan CA. Tidak ada hubungan yang ditemukan antara ketiga genotipe dengan komponen karkas di pada populasi persilangan ayam Kampung $\mathrm{x}$ ras pedaging $\mathrm{F} 2$.
\end{abstract}

Kata-kata kunci: TGF-ק3, genotipe, karkas, ayam Kampung, persilangan

\section{INTRODUCTION}

Fullfilment of the animal protein needs can not be separated from the productivity of livestock in producing meat, eggs, or milk. In Indonesia, consumption of animal protein from meat is dominated by broilers. Local chicken farms, including Kampung chickens, have not fully developed yet due to multiple factors. Growth is one of a primary challenge for native chicken production. With an intensive rearing system, native chickens in Indonesia reach slaughter weights at 4.5 months or more (FAO 2008). This is very distinct from broiler chickens (Ross 308 strains) that capable of reaching a weight of $1.4 \mathrm{~kg}$ at 28 days (Zuidhof et al. 2014). Improving the performance of native chickens can be done by selection or crossing, or both selection and crossbreeding together (Sheng et al. 2013, Padhi 2016). Abdurrahman et al. (2016) reported that crossbreeding of local crossed chickens produced lower fat and cholesterol compared to broilers. Further, Sheng et al. (2013) explained that crossbreeding between native chickens and fast-growing commercial broilers to produce F2 is also an effective 
method for evaluating the potential genetic enhancement of native chickens.

Muscle growth in livestock is influenced by three main hormones namely steroids, transforming growth factor-beta (TGF- $\beta$ ), and myostatin (Dayton \& White 2007). TGF- $\beta$ is a family of growth factor hormones that regulate biological activity in a very broad range such as morphogenesis (Lorda-Diez et al. 2010), development (Lu et al. 2013), production (Jin et al. 2013), reproduction (Gu et al. 2017), and disease resistance (Muhsinin et al. 2017). A previous study by Li et al. (2003) showed that TGF- $\beta 3$ plays a dominant role in growth, especially body weight and average daily gain (ADG). Morover, Li et al. (2003) mentioned that there was an association of TGF- $\beta 3$ gene diversity with body weight, ADG, carcass percentage, and chest weight in broiler chicken. The study of the relationship of TGF- $\beta 3$ gene diversity with parameters of chicken carcasses in Indonesia have never been reported before. The aims of this study were to identify the TGF$\beta 3 \mid B s l$ locus polymorphisms and to evaluate their effects on carcass components in Kampung and broiler chicken cross.

\section{MATERIALS AND METHODS}

\section{Animal and Data Collection}

A total of 129 chickens used in this study, consisting of 4 populations: Kampung chickens $(K, n=44)$, parent stock broilers Cobb strains (B, n=10), F1 Kampung x broiler chickens cross $(\mathrm{KB}, \mathrm{n}=35)$, and $\mathrm{F} 2 \mathrm{~KB} \times \mathrm{KB}$ (KBKB, $n=40)$. All of these chickens were a collection of the Animal Breeding and Genetics Division, Department of Animal Production and Technology, Faculty of Animal Husbandry, IPB. All chickens were kept under uniform environment conditions to reduce the influence of environmental diversity. Blood samples were collected from a wing vein. The blood sample was then added with an ethylenediamine tetraacetic acid (EDTA) anticoagulant. The F2 KBKB (21 male and 19 female) were slaughtered at 26 weeks to obtain carcass composition data. Carcass component data consisted of live weight (26 weeks), carcass weight, commercial cut weight (breast, thigh, drumstick, and wings), and muscle weight (breast, thigh, and drumstick).

\section{Genomic DNA Extraction}

DNA isolation procedure was carried out using the Sambrook and Russel (2001) with some modifications. A total of $20 \mu \mathrm{l}$ of fresh blood was added with $1000 \mu \mathrm{l}$ of $\mathrm{NaCl}$ $0.2 \%$, then thoroughly shaken until homogeneous. The sample was then centrifuged at $800 \mathrm{rpm}$ for five minutes to form a precipitate, while the supernatant was removed. The precipitate was added with $350 \mu 11$ x STE, $40 \mu 1$ 10\% SDS and $10 \mu$ Proteinase $\mathrm{K} 5 \mathrm{mg} / \mathrm{ml}$ and then incubated for two hours at $55^{\circ} \mathrm{C}$. After that, $400 \mu$ phenol, $400 \mu$ l CIAA and $40 \mu \mathrm{l} \mathrm{NaCl} \mathrm{5M}$ were added, then slowly shaken at room temperature for one hour. The next step was centrifugation at $12000 \mathrm{rpm}$ for five minutes. A total of $400 \mu \mathrm{l}$ of clear liquid in the upper layer was transferred to a new tube and was added with $800 \mu \mathrm{l}$ absolute EtOH and $40 \mu \mathrm{l} \mathrm{NaCl} 5 \mathrm{M}$ were then frozen for 12 hours. The sample was then centrifuged at $12000 \mathrm{rpm}$ for five minutes and a white precipitate was formed. The precipitate was air drained and added with 100 $\mu 1$ of TE $80 \%$. The DNA sample was then stored at $-20{ }^{\circ} \mathrm{C}$ for further use.

\section{Amplification and Genotyping}

Specific sequence of the TGF- $\beta 3$ locus were obtained using a thermocycler machine (GeneAmp ${ }^{\circledR}$ PCR System 9700, Applied Bio Systems TM, Foster City, CA, USA) with the polymerase chain reaction (PCR) technique. The 30 cycles of PCR process consisted of denaturation $\left(95^{\circ} \mathrm{C}\right.$ for 10 seconds), annealing $\left(60^{\circ} \mathrm{C}\right.$ for 20 seconds), and extension $\left(72^{\circ} \mathrm{C}\right.$ for 30 seconds). The primers used for obtaining a 294 bp fragment target in intron 4 were F: 5'TCA GGG CAG GTA GAG GGT GT-3' and R: 5'-GCC ACT GGC AGG ATT CTC AC-3', according to Li et al. (2003). Amplification was carried out in a total volume of $25 \mu \mathrm{L}$, consisting of $50 \mathrm{ng} / \mu \mathrm{L}$ DNA templates, $0.5 \mathrm{pmol}$ primers, 0.5 units of GoTaq Green Master Mix (Promega, Madison, WI, USA), and water.

Genotyping was performed using restriction fragment length polymorphism (RFLP) techniques. PCR products and restriction enzymes (Thermo Fisher Scientific, EU, Lithuania) were incubated for 12 hours at $55^{\circ} \mathrm{C}$. The DNA bands were visualized using agarose gel electrophoresis with a concentration of $2.5 \%(\mathrm{v} / \mathrm{w})$ and FluoroSafe DNA Staining (1st Base, Singapore) under the UV Transilluminator machine (Alpha Imager, Alpha Innotech, Santa Clara, CA, USA). The SNP target position is in intron 4 position can be seen in Figure 1. To confirm the mutation, three samples each genotype were performed direct sequencing analysis through Sanger DNA Sequencing 1st Base (Singapore, Singapore) services with ABI-PRISM3730 sequencer.

\section{Data Analysis}

Polymorphism Information and Sequencing. Polymorphism information (genotype frequency, allele frequency, and heterozygosity) were analyzed based on Nei and Kumar (2000). All sequencing results (ABI trace files) were analyzed using Molecular Evolutionary Genetic Analysis (MEGA) 6.0 software based on Tamura et al. (2013) and BioEdit (Hall 2011). The Basic Local Alignment Search Tool (BLAST) application was applied to identify gene homology with the data base on Ensembl (https://asia. ensembl.org/index.html).

Statistical analysis. Genotype associations with carcass composition were analyzed by the GLM procedure using the Statistical Analysis System (SAS) 9.4 (SAS Institute 2013) and were followed by Duncan's tests. Genetic influence was analyzed based on the following model,

$$
\mathrm{yij}=\mu+\mathrm{Gi}+\varepsilon \mathrm{ij}
$$

where yij is the observed phenotype (carcass composition) in the $\mathrm{j}$ individuals, and the $\mathrm{i}$ - genotype; $\mu$ is the general mean; $\mathrm{Gi}$ is the genetic influence of the i-genotype; and $\varepsilon \mathrm{ij}$ is a normally distributed residual error. 


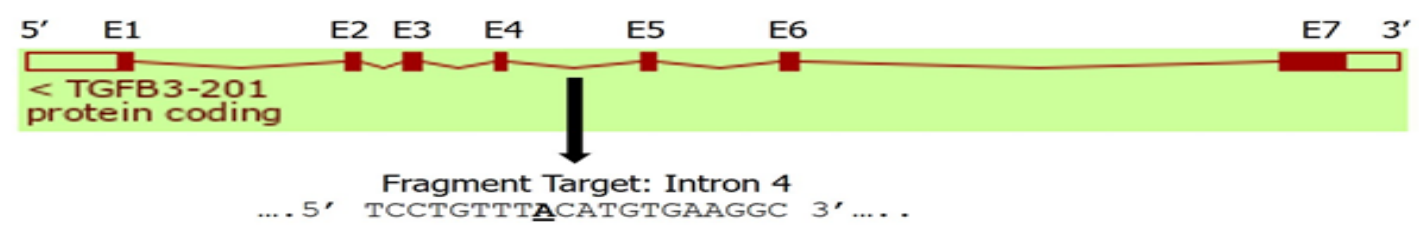

Figure 1. Fragment target TGF- $\beta 3$ |BslI locus. Underline shows SNP position; E=exon (Ensembl accession number: ENSGALG00000010346)

\section{RESULTS AND DISCUSSSION}

\section{The TGF- $\beta 3 \mid B s l$ I Gene Polymorphism}

The fragment target of the TGF- $\beta 3$ locus showed the same sequence length with the reference sequence (Ensembl accession number: ENSGALG00000010346), which was 294 bp. After being digested with the BslI restriction enzyme, two alleles, namely $\mathrm{C}$ and A allele, were obtained. There were three restriction points of the $B s l$ I enzyme along the $294 \mathrm{bp}$. The A allele had two restriction sites which were indicated by three fragments: 145, 75 and 74 bp (Figure 2). While, the $\mathrm{C}$ allele had three restriction which produced four fragments: 125, 75, 74, and $20 \mathrm{bp}$ (Figure 2). The two alleles formed a combination of three genotypes namely CC, CA, and AA. The results of RFLP analysis on 129 chicken samples revealed all three genotypes. The transversion mutation of base $\mathrm{C}$ to $\mathrm{A}$ at $89 \mathrm{bp}$ can be found in the DNA sequencing results (Figure 3 ). The genotype frequency, allele frequency, Ho, and He of the TGF- $\beta 3 \mid$ BslI locus in the chickens studied can be found in Table 1 .
The results of the allele frequency calculation showed that the A allele was predominant in the $\mathrm{K}, \mathrm{KB}$, and $\mathrm{KBKB}$ populations, while the $\mathrm{C}$ allele was pedominant in the B population. According to Nei and Kumar (2000), the entire population studied was polymorphic because it had two or more alleles in one locus with a large enough frequency (usually more than 1\%). The estimation of heterozygosity values aims to determine the level of polymorphism of an allele so that it can be used for the selection program. The observed heterozygosity (Ho) value at the TGF- $\beta 3 \mid$ BsII locus indicated a higher value than the expected heterozygosity value $(\mathrm{He})$. This indicated that there was no intensive selection process based on this locus (Allendorf et al. 2013). The diversity at the TGF- $\beta 3$ locus showed that the genetic diversity of Kampung chickens was higher than broiler (Table 1). These results were in line with the findings of Riztyan et al. (2011) which stated that the free-range chicken populations such as Kampung chickens showed high genetic diversity due to the lack of selection occured.

Table 1. Genotype, allele frequency, and heterozygosity of TGF- $\beta 3 \mid$ BslI locus in Indonesian chickens

\begin{tabular}{|c|c|c|c|c|c|c|c|c|}
\hline \multirow[t]{2}{*}{ Population } & \multirow[t]{2}{*}{$\mathrm{N}$} & \multicolumn{3}{|c|}{ Genotype Frequency } & \multicolumn{2}{|c|}{ Allele Frequency } & \multirow[t]{2}{*}{ Но } & \multirow[t]{2}{*}{$\mathrm{He}$} \\
\hline & & $\mathrm{AA}$ & $\mathrm{CA}$ & $\mathrm{CC}$ & $\mathrm{C}$ & $\mathrm{A}$ & & \\
\hline Kampung (F0) & 44 & 0.273 & 0.614 & 0.114 & 0.42 & 0.58 & 0.614 & 0.487 \\
\hline Broiler (F0) & 10 & 0 & 0.700 & 0.300 & 0.65 & 0.35 & 0.700 & 0.455 \\
\hline $\mathrm{KB}(\mathrm{F} 1)$ & 35 & 0.229 & 0.743 & 0.029 & 0.40 & 0.60 & 0.743 & 0.480 \\
\hline KBKB (F2) & 40 & 0.350 & 0.600 & 0.050 & 0.35 & 0.65 & 0.600 & 0.455 \\
\hline
\end{tabular}

$\mathrm{N}$ : Number of samples

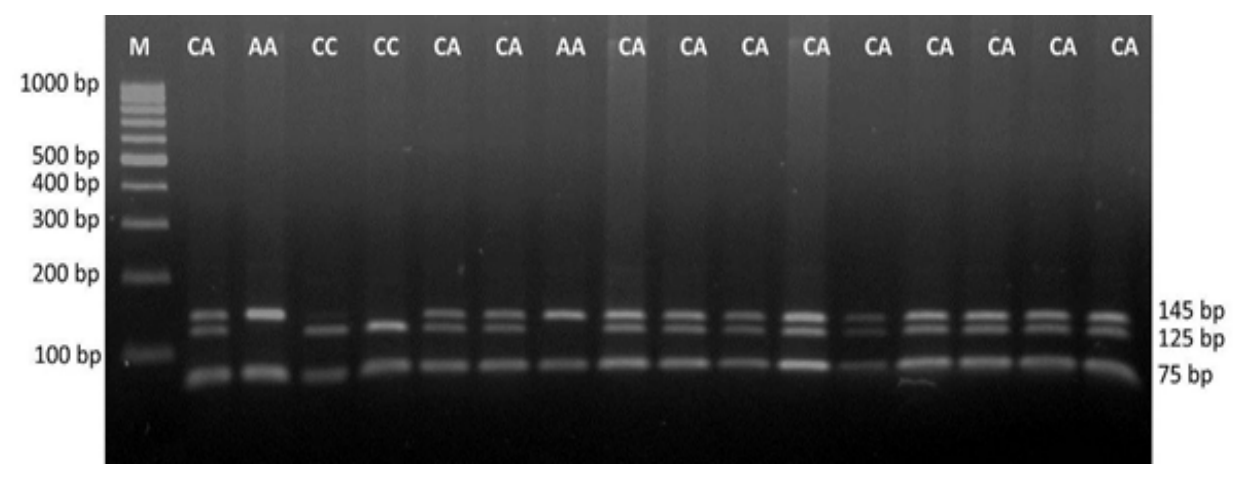

Figure 2. Genotyping of the TGF- $\beta 3 \mid$ BslI locus in $2.5 \%$ agarose gel. M=DNA ladder; CC, CA, AA= genotype 


TGFB3_ENSGALG00000010346
AA
AA
CA
CA
CC
CC

TGFB3_ENSGALG00000010346
AA
AA
CA
CA
CC
CC

TGFB3_ENSGALG00000010346
AA
AA
CA
CA
CC
CC

TGFB3_ENSGALG00000010346
AA
AA
CA
CA
CC
CC

TGFB3_ENSGALG00000010346

AA
AA
CA
CA
CC
CC
TGFB3_ENSGALG00000010346
AA
AA
CA
CA
CC
CC

Forward primer

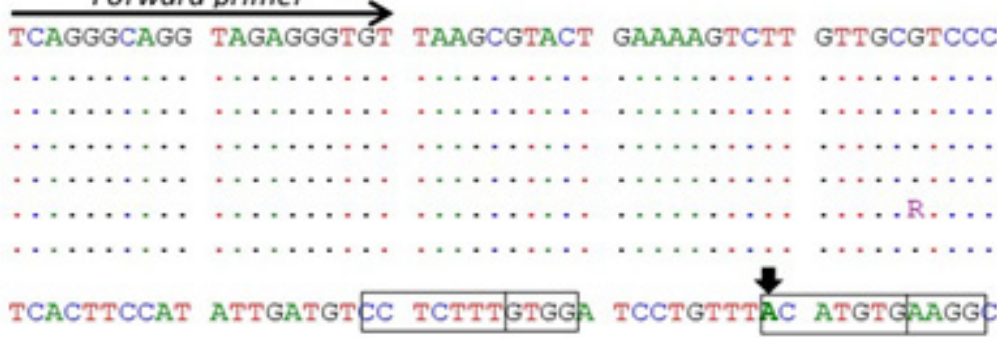

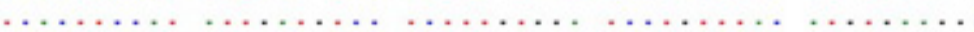

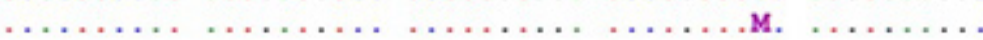

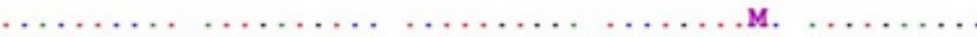

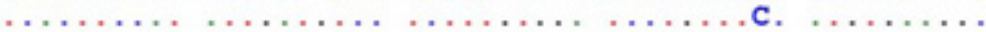

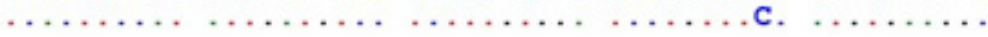

ATTGACAGTG AAGATGACTA TGGCCGTGGG GACTTGGGGC GCCTGAAGAA

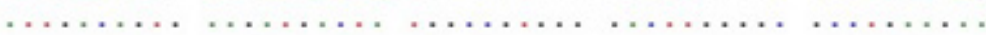

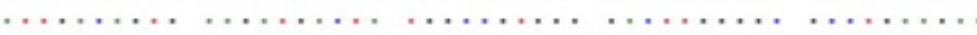

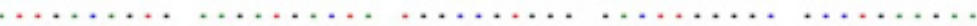

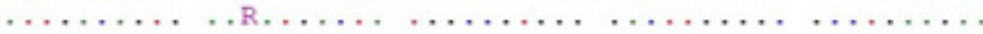

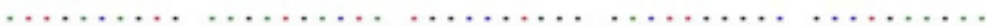

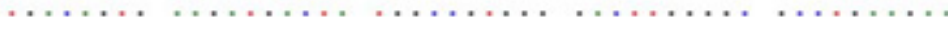

GCAGAAAGAC TTGCATAATC CCCACCTCAT CTTGATGATG CTACCCCCAC

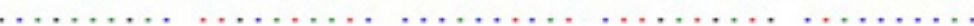

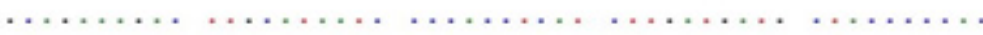

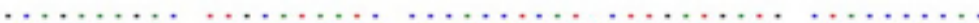

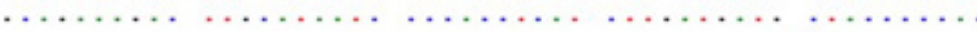

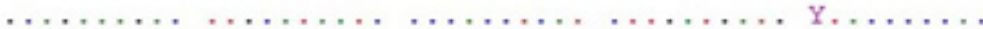

201 ATCGCCTGGA GAGCCCAACA CTGGGAGGCC AGAGAAAGAA GCGGGCCCTG

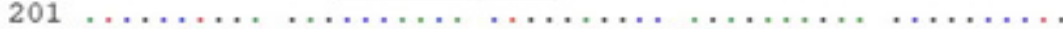

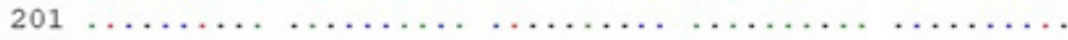

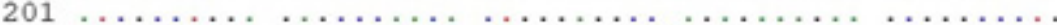

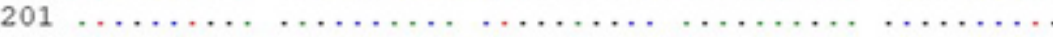

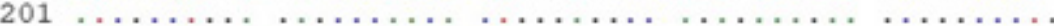

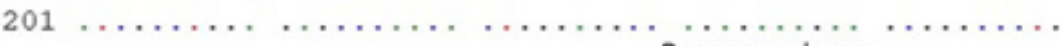

Reverse primer

GATACCAACT ACTGCTTCCG GTAAGTGGA ATCCTGCCAG TGGC

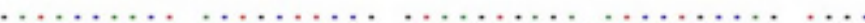

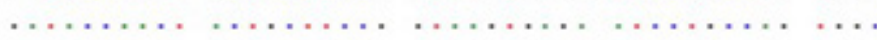

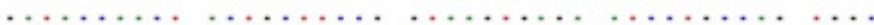

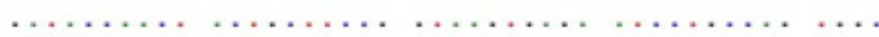

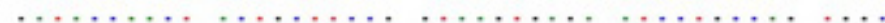

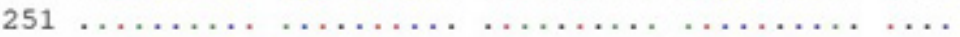

(C>A) CNNNNN NNGG BsII cut site $(75,95,220 \mathrm{bp})$

Mutation site $\mathrm{C}>\mathrm{A}(89 \mathrm{bp})$

Figure 3. Nucleotide sequence of chicken TGF- $\beta 3$ partial gene. Arrow shows $\mathrm{C}$ to A mutation in intron 4. Boxes show BsII restriction sites. M=IUPAC code for A or $\mathrm{C}$.

\section{The Effects of TGF- $\beta 3 \mid$ Bs $l$ I Locus Polymorphisms with Carcass Components}

The association of the TGF- $\beta 3 \mid B s l$ l locus showed that genotypes (CA, CC, and AA) had no significant effect on all carcass components in both male and female chicken populations (Table 2). Previous study by Li et al. (2003) showed that the CA genotype (encoded with BL genotype) had a significant effect on body weight at 2 weeks, ADG at 0-2 weeks, shank weight, breast muscle weight, abdominal fat weight, and spleen weight.
The TGF- $\beta$ superfamily is known to have a strong function in muscle regulation. There are three subtypes of the TGF- $\beta$ namely TGF- $\beta 1$, TGF- $\beta 2$, and TGF- $\beta 3$ (Gumucio et al. 2015). The TGF- $\beta 1$ gene is reported to regulate muscle cell damage and regeneration (Kim \& Lee 2017). Study of Lu et al. (2013) showed that both TGF- $\beta 2$ and TGF- $\beta 3$ may play important roles in fetal myoblasts proliferation in chicken leg muscles. Whereas in human, signaling of the TGF- $\beta 3$ gene is known to regulate the normal growth of skeletal muscle (Reinhoff et al. 2013). The myostatin 
Khaerunnisa et al.

Jurnal Ilmu Produksi dan Teknologi Hasil Peternakan 8 (1): 42-47

Table 2. The association of TGF- $\beta 3$ |Bsil polymorphism on carcass components in F2 Kampung x broiler chickens

\begin{tabular}{|c|c|c|c|c|c|c|c|}
\hline \multirow[t]{2}{*}{ Trait } & \multicolumn{7}{|c|}{ Genotype } \\
\hline & \multicolumn{3}{|c|}{$\mathrm{CA}$} & \multirow{2}{*}{$\begin{array}{c}\mathrm{CC} \\
\mathrm{n}=1 \\
\end{array}$} & \multicolumn{3}{|c|}{ AA } \\
\hline Female & $\mathrm{n}$ & $=$ & 13 & & $\mathrm{n}$ & $=$ & 5 \\
\hline Carcass weight (gr) & 1508.54 & + & 390.19 & 1152 & 1225.20 & + & 356.12 \\
\hline Breast weight (gr) & 421.77 & + & 133.30 & 293 & 318.20 & + & 102.25 \\
\hline Thigh weight (gr) & 266.62 & + & 71.58 & 193 & 215.00 & + & 60.15 \\
\hline Drumstick weight (gr) & 243.08 & + & 61.23 & 165 & 199.80 & + & 47.46 \\
\hline Wings weight (gr) & 212.69 & + & 48.57 & 184 & 171.60 & + & 50.51 \\
\hline Breast muscle weight (gr) & 310.85 & + & 109.76 & 181 & 232.00 & + & 84.20 \\
\hline Thigh muscle weight (gr) & 195.46 & + & 47.56 & 127 & 154.60 & + & 52.05 \\
\hline Drumstick muscle weight (gr) & 159.85 & + & 41.91 & 98 & 128.80 & + & 36.32 \\
\hline Male & $\mathrm{n}$ & $=$ & 11 & $\mathrm{n}=1$ & $\mathrm{n}$ & $=$ & 9 \\
\hline Carcass weight (gr) & 1515.55 & + & 349.13 & 1112 & 1648.22 & + & 298.48 \\
\hline Breast weight (gr) & 356.09 & + & 86.90 & 281 & 429.56 & + & 78.43 \\
\hline Thigh weight (gr) & 289.09 & + & 81.96 & 215 & 323.33 & + & 63.22 \\
\hline Drumstick weight (gr) & 290.45 & + & 67.89 & 184 & 327.00 & + & 57.23 \\
\hline Wings weight (gr) & 209.55 & + & 44.56 & 168 & 236.78 & + & 40.02 \\
\hline Breast muscle weight (gr) & 256.00 & + & 75.26 & 198 & 294.67 & + & 76.60 \\
\hline Thigh muscle weight (gr) & 220.09 & + & 66.77 & 159 & 218.78 & + & 54.55 \\
\hline Drumstick muscle weight (gr) & 187.00 & + & 48.56 & 113 & 208.11 & + & 46.95 \\
\hline
\end{tabular}

n: Number of samples

gene, one of the newest members of the TGF- $\beta$ family, was reported to have an association with carcass composition and quality of chicken meat (Khaerunnisa et al. 2016).

Exploration of the function and effect of the TGF- $\beta 3$ gene on muscle growth and regulation in chickens is still very limited. Although the results of this study were not significantly different, this study might be able to provide the role of the TGF- $\beta 3$ gene in carcass components. The difference with Li et al. (2003) may caused by chicken breed differences and limited number of samples, especially the $\mathrm{CC}$ genotype. Further studies are required in a large chicken population to prove the role of TGF- $\beta 3$ gene.

\section{CONCLUSION}

Kampung, broiler, and its cross were polymorphic according to the TGF-B3|BslI genotypes. These genotypes did not appear to influence chicken carcass components in F2 Kampung $\mathrm{x}$ broiler cross. This gene cannot be recommended as a marker for selection of improving carcass production since there is no association with the carcass component.

\section{ACKNOWLEDGEMENT}

Authors thank to PMDSU Research Grant from The Ministry of Research, Technology, and Higher Education, Republic of Indonesia, which financially supported this work.

\section{REFERENCES}

Abdurrahman, Z. H, Y. B. Pramono, \& N. Suthama. 2016. Meat characteristic of crossbred local chicken fed inulin of dahlia tuber and Lactobacillus sp. Med. Pet. 39:112118. https:// doi.org/10.5398/medpet.2016.39.2.112

Allendorf, F. W., G. Luikart, \& S. N. Aitken. 2013. Conservation and the Genetics of Population 2nd Ed. Wiley-Blackwell Publishing, UK.

Dayton, W. R. \& M. E. White. 2008. Cellular and molecular regulation of muscle growth and development in meat animals. J. Anim. Sci. 86:217-225. doi: 10.2527/ jas.2007-0456

FAO. 2008. Local chicken genetic resources and production systems in Indonesia. Prepared by Muladno Muladno. GCP/ RAS/228/GER Working Paper No. 6. Rome.

Gu, L., C. Sun, Y. Gong, M. Yu \& S. Li. 2017. Novel copy number variation of the TGF $\beta 3$ gene is associated with TGF $\beta 3$ gene expression and duration of fertility traits in hens. PLoS ONE 12(3): e0173696. doi: 10.1371/ journal. pone. 0173696

Gumucio, J.P., K. B. Sugg, \& C. L. Mendias. 2015. TGF- $\beta$ superfamily signaling in muscle and tendon adaptation to resistance exercise. Exerc. Sport. Sci. Rev. 43:93-99.

Hall, T. 2011. BioEdit: An important software for molecular biology. GERF Bulletin of Biosciences 2:60-61.

Jin, S., S. Chen, H. Li, Y. Lu, D. Zhang, C. Ji, G. Xu \& N. Yang. 2013. Polymorphisms in the transforming growth factor $\beta 3$ gene and their associations with feed efficiency in chickens. Poult. Sci. 92 :1745-1749. doi: 10.3382/ps.2013-03018 
Khaerunnisa, I., M. Pramujo, I. I. Arief, C. Budiman, A. Gunawan, Jakaria, \& C. Sumantri. 2016. Polymorphism of the T4842G myostatin gene is associated with carcass characteristics in Indonesian chickens. Intl. J. Poult. Sci. 15 (8): 316-324

Kim, J. \& J. Lee. 2017. Role of transforming growth factor- $\beta$ in muscle damage and regeneration: focused on eccentric muscle contraction. Journal of Exercise Rehabilitation 13(6):621-626

Li, H., N. Deeb, H. Zhou, A. D. Mitchell, C. M. Ashwell \& S. J. Lamont. 2003. Chicken quantitative trait loci for growth and body composition associated with transforming growth factor- $\beta$ genes. Poult. Sci. 82:347-356

Lorda-Diez, C. I., J. A. Montero, J. A. Garcia-Porrero \& J. M. Hurle. 2010. Tgf 32 and 3 are coexpressed with their extracellular regulator Ltbplin the early limb bud and modulate mesodermal outgrowth and BMP signaling in chicken embryos. BMC Dev. Biol. 10 (69). doi: 10.1186/1471-213X-10-69

Lu, Y., S Chen \& N. Yang. 2013. Expression and methylation of FGF2, TGF-B and their downstream mediators during different developmental stages of leg muscles in chicken. PLoS ONE 8(11): e79495. doi:10.1371/ journal.pone.0079495

Muhsinin, M., N. Ulupi, A. Gunawan, I. W. T. Wibawan \& C. Sumantri. 2017. g.640T $>$ C Polymorphism of the TGF- $\beta 2$ Gene is Associated with Salmonella pullorum Resistance in Indonesian Chicken. Anim. Prod. 19(2):81-92

Nei, M. \& S. Kumar. 2000. Molecular Evolution and Phylogenetic. Oxford University Press, New York.

Padhi, M. K. 2016. Importance of indigenous breeds of chicken for rural economy and their improvements for higher production performance. Scientifica 2016. http://dx.doi. org/10.1155/2016/2604685.
Rienhoff, H. Y. Jr, C. Y. Yeo, R. Morissette, I. Khrebtukova, J. Melnick, S. Luo, N. Leng, Y. J. Kim, G. Schroth, J. Westwick, H. Vogel, N. McDonnell, J. G. Hall, \& M. Whitman M. 2013. A mutation in TGFB3 associated with a syndrome of low muscle mass, growth retardation, distal arthrogryposis and clinical features overlapping with Marfan and Loeys-Dietz syndrome. Am. J. Med. Genet. A. 161A(8):2040-6. doi: 10.1002/ ajmg.a.36056

Riztyan, T. Katano, T. Shimogiri, K. Kawabe, \& S. Okamoto. 2011. Genetic diversity and population structure of Indonesian native chickens based on single nucleotide polymorphism markers. Poult. Sci. 90 :2471-2478. doi: 10.3382/ps.2011-01450

Sambrook, J. \& D. Russell. 2001. Molecular Cloning: A Laboratory Manual 3rd Ed. Cold Spring Harbor Laboratory Press, USA.

SAS Institute. 2008. SAS/STAT ${ }^{\circledR} 9.2$ User's Guide The GLM Procedure (Book Excerpt). SAS Institute Inc. Cary, NC, USA.

Sheng, Z., M. E. Pettersson, X. Hu, C. Luo, H. Qu, D. Shu, X. Shen, Ö. Carlborg, \& N. Li. 2013. Genetic dissection of growth traits in a Chinese indigenous $\times$ commercial broiler chicken cross. Genomics 14:151. http://dx.doi. org/10.1186/1471-2164-14-151.

Tamura, K., G. Stecher, D. Peterson, A. Filipski, \& S. Kumar. 2013. MEGA6: Molecular Evolutionary Genetics Analysis Version 6.0. Mol. Biol. Evol. 30:2725-2729. https://doi. org/10.1093/molbev/mst197

Zuidhof, M. J., B. L. Schneider, V. L. Carney, D. R. Korver, \& F. E. Robinson. 2014. Growth, efficiency, and yield of commercial broilers from 1957, 1978, and 2005. Poult. Sci. 93: 2970-2982. doi: 10.3382/ps.2014-04291. 